\title{
Social Media and Changes in Students' Learning and Social Behaviors
}

\author{
Tetep $^{1}$, Eldi Mulyana ${ }^{2}$, Triani Widyanti ${ }^{3}$, Yopi Nugraha \\ $\left\{\right.$ tetep@institutpendidikan.ac.id ${ }^{1}$, eldimulyanabindedih@institutpendidikan.ac.id ${ }^{2}$, \\ trianiwidyanti@institutpendidikan.ac.id ${ }^{3}$ \} \\ Institut Pendidikan Indonesia, Jl. Terusan Pahlawan No.83, Garut $44151^{123}$
}

\begin{abstract}
The development of information technology has brought about various types and forms of digital interaction facilities. Digital interaction has changed students' mindsets and behaviours both in learning and social interactions. Using a quantitative approach, this study describes (1) Are there differences in the orientation of social media use between male and female students in Higher Education in Garut Region, (2) What is the impact of social media on changes in student learning behavior at Higher Education in Garut Region (3) What is the impact of social media on changes in student social behavior at Higher Education in Garut Region. The results of this revealed that social media become the most widely used platform for digital interaction by students, that there is not different using social media between male and female students in Garut. There is correlation 25,4\% using social media to learning behaviour change and then are correlation $68,1 \%$ media social to social behaviour change at higher education students in Garut. It is necessary for higher education institutions to develop a social media-based learning culture through periodical training to make the most of social media for educational and social purposes.
\end{abstract}

Keywords: social media, learning behaviours, social behaviours.

\section{Introduction}

The Industrial Age 4.0 was characterized by the proliferation of digitization systems in every aspect of life such as social, political, legal, economic and even education. Social media has become a means of communication which until now has been considered more effective in influencing readers and users of social media. In the study We are Social and Hootsuite (2018) there were 130 million Indonesian occupations actively using social media, 132.7 million using the internet, $48 \%$ of Indonesia's population tasting social media and $92 \%$ of social media users coming from mobile devices or smartphones and around 177.9 million Indonesians have used these mobile devices with an average of 3 hours 23 minutes per day or around 4 hours per day.

Table 1.1 Figures of Used of Social Media in Indonesia January 2018

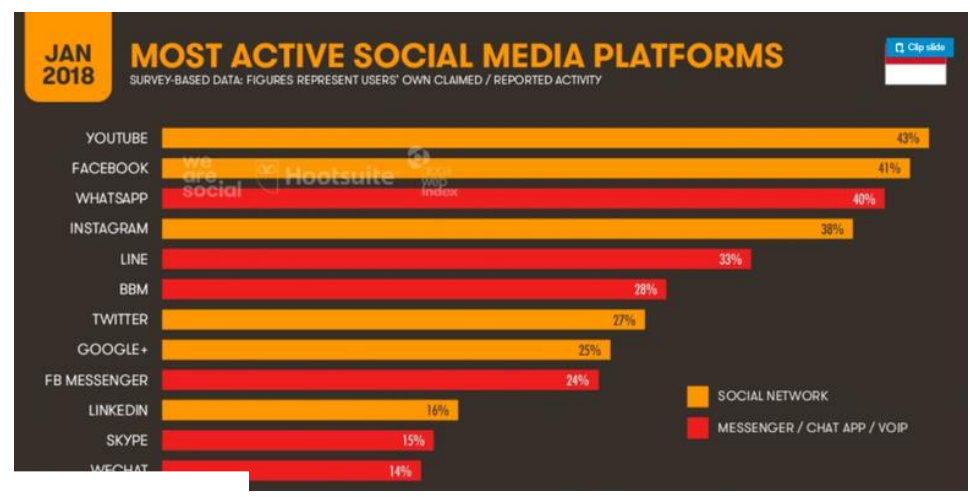


The use of social media will certainly affect the users themselves in thinking and acting both personally and in groups. This influence then has the potential for changes in social behaviour including one's learning behaviour. Social media is used by the majority of millennials and students become one part of the millennial generation which tends to use more social media to communicate. Survey of the Indonesian Internet Service Providers Association (APJII, 2017) that there are 143.26 million Indonesians who have used the internet, out of a total population of 262 million. That means there is 54.86 per cent of Indonesians who are connected to the internet. There are $49.52 \%$ of age between $19-34$ years dominating the use of social media, this age group is referred to as the millennial generation and will increase in the next $50-60 \%$ of users.

Joseph Yoo, etc. (2017) in his research explained that social media in political activities is a new form of online politics to involve the masses in political activities even though they are hidden. The generation that grew up when the internet culture was born was called a digital native or millennial generation. Supratman and Wahyudin (2017) suggest that this generation is seen as a future generation that is nurtured in a new cultural environment of digital media that is interactive, desolate (personal), communicates personally, and computer literacy.

Meanwhile, according to Amofah \& Dadzie (2015) that every digital native day spends $79 \%$ of its time accessing the internet. Kaplan \& Haenlein (2010) suggested that social media is an internet-based application service that allows users to share their opinions, thoughts, perspectives and experiences. Some experts, such as Laughey and Mc Quail (in Nasrullah, 2017) also explain that social media is a communication tool. Meanwhile, Fuchs (in Nasrullah, 2017) argues that the social definition in social media is that individuals in a community not only exist in an environment but must collaborate with other environments to create cooperation because cooperation is a character of the social. The negative effects of social media include a decrease in life satisfaction (Kross, et al., 2013; Mc.Dool, Powell, Roberts \& Taylor, 2016; Tromholt, 2016). Rush sleep quality, anxiety and low self-esteem, shame, and symptoms of depression (Woods \& Scott, 2016; Hanna, et. Al., 2017; Lin, et. Al., 2016; Lup, Trub \& Rosenthal, 2015 )

There are also positive effects of using social media such as eliminating loneliness, increasing life satisfaction, expression (Pittman \& Reich, 2016; Yang, 2016). Some of these studies describe that social media has an important role in influencing its actions, thoughts and experiences. In this study, the author's focus is on how the use of social media has an impact on changes in social behaviour and student learning behaviour in Garut Regency. Social behavior is a person's physical and psychological activity towards others to meet the demands of himself and others (Hurlock, 1995) while learning behaviour is a relatively long change that occurs from experiences (Davidoff, 1998).

Changes in social behaviour and learning generally occur as a result of interaction and communication with the surrounding environment and experience. This behaviour can be positive and negative. Interaction and communication are now mostly carried out on social media, so social media is one that has the potential to change students' social behaviour and learning behaviour in Garut Regency. The focus of this study includes 1) whether there are differences in the orientation of social media use between male and female students at the Indonesian Institute of Education, 2) What is the impact of social media on changes in student learning behaviour at the Indonesian Education Institute, 3) How does social media affect changes in student social behavior at the Indonesian Institute of Education. 


\section{Research Method}

This research is quantitative research by testing hypotheses or solving problems based on theoretical deduction, by measuring using statistical data. The type of quantitative research used is an associative quantitative causal relationship where according to Neuman (2013) this study was conducted to determine the causal relationship between independent variables (influencing variables) and dependent variables (variables that are affected). Determination of associative quantitative research method according to Sudjana (2014) is based on the suitability of the method with the research title aimed at finding the influence between independent variables (utilization of social media) and the dependent variable (changes in learning behaviour and social behaviour). Students from 3 major universities in Garut Regency were determined randomly. Furthermore, the data is processed and analyzed using SPSS Statistics 23. The following table relates to respondents based on gender and the effectiveness of using social media as a learning medium:

Table 2.1 Data on Respondent by sex

\begin{tabular}{cccccc}
\hline \multirow{2}{*}{ Sex } & \multicolumn{2}{c}{ University Background } & $\begin{array}{c}\text { Number of } \\
\text { Respondents }\end{array}$ & Presents \\
\hline & IPI & UNIGA & STTG & & \\
\hline Male & 35 & 25 & 18 & 78 & $42 \%$ \\
\hline Female & 49 & 38 & 21 & 108 & $58 \%$ \\
\hline Amount & & & & 186 & $100 \%$ \\
\hline Source : Pengolahan data responden, 2019 & & &
\end{tabular}

Based on the table of respondents, there were 108 student respondents from women consisting of 49 students from IPI, 38 students from UNIGA and 21 students from STTG; it was suspected that universities in Garut Regency were dominated by women. There were 78 male student respondents consisting of 35 students from IPI, 25 students from UNIGA and 18 STTG students.

\section{Result and Discussion}

Referring to the formulation of the main problem in this study can be elaborated the essence of this research is the orientation of social media use between male and female students in Garut Regency. Based on the results of a survey of students at three universities in Garut Regency, it can be explained in the following table below. 


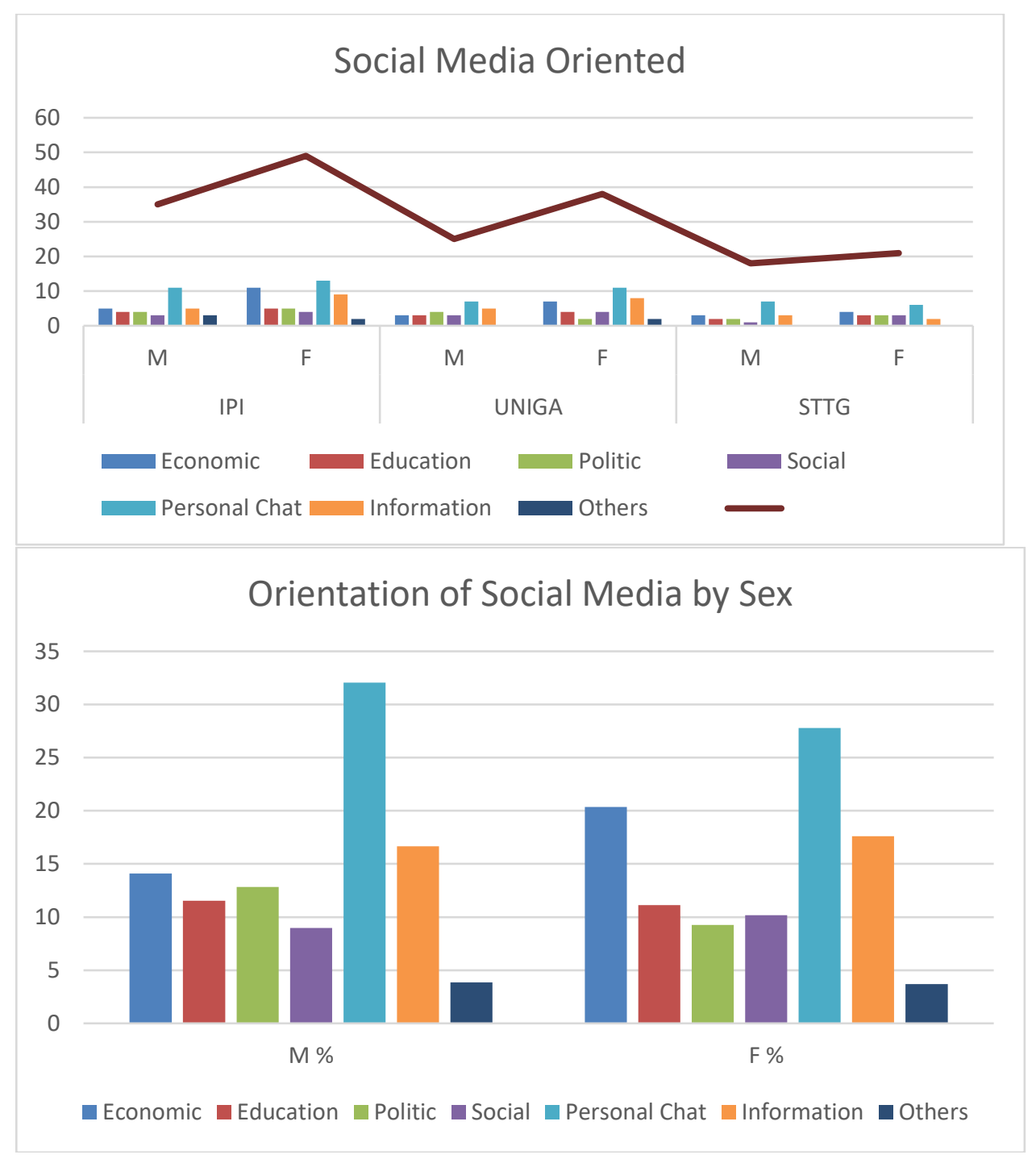

Source : Date Analisys 2019

Fig 1. Social Media Orientation

The table shows that the orientation of students, both male and female, have the same orientation which is more dominant for the selection of personal chat, male students $33 \%$ and female students $27 \%$, personal chat interests are usually related to personal interests, there are differences in orientation it turns out that the economic orientation is dominated by female students, which is $21 \%$ while men are only $13 \%$. Then the information needs only by receiving information, sharing or forwarding the information they are doing. Thus, in general, there is no difference in the orientation of the use of social media by male and female students in Garut Regency. The orientation of the use of student social media for personal interests becomes a habit that is currently being done. The pattern of using social media refers to habits and 
frequency by people who are accustomed to dealing with social media (McQuail, 2011). Some people according to Turkle (2005) treat computers as if the object is a human being that is used as a place of emotional overflow.

The impact of social media on student learning behaviour in Garut Regency can be seen in the results of non-parametric SPSS calculations with Spearman rho analysis as follows:

\section{Table 3.1 Correlation}

\begin{tabular}{lll|c|c}
\hline \multicolumn{4}{c}{ Correlations } \\
\hline \multirow{2}{*}{ Spearman's rho } & \multicolumn{1}{c|}{ SocMed } & Correlation Coefficient & SocMed & Learning \\
\cline { 3 - 5 } & & Sig. (2-tailed) & 1.000 & $.254^{* *}$ \\
\cline { 3 - 5 } & $\mathrm{N}$ &. & .001 \\
\cline { 3 - 5 } & \multirow{2}{*}{ Learning } & Correlation Coefficient & $.254^{* *}$ & 1.000 \\
\cline { 3 - 5 } & & Sig. (2-tailed) & .001 &. \\
\cline { 3 - 5 } & $\mathrm{N}$ & 186 & 186 \\
\hline
\end{tabular}

The relationship between Social Media variables with Changes in Learning Behavior in students based on table 3.2 can be stated that the results of the Spearman's rho correlation coefficient test get a value of $\mathrm{rs}=0.254$ or $25.4 \%$, with $\mathrm{P}$-value $=0.001$ smaller than the value $\alpha=0.05$, then can be reacted $\mathrm{Ho}=$ rejected. Thus, social media has a significant influence on changes in student learning behaviour at universities in Garut Regency, namely $25.4 \%$ or strong enough. Social media is one of the factors that can influence student learning behaviour and actions. Social media not only shapes behaviour towards economic activities but also academic communication. The media is being used in all manners of communication ranging from personal and academic communications (Campbell \& Craig, 2014) to professional, healthrelated communications (Shaffer-Hudkins, Johnson, Melton, \& Wingert, 2014; Adewuyi \& Adefemi, 2016). Nowadays, universities in academic services have used digital systems, even in 3 universities where the authors have all used online-based services, indirectly changing the manual habits with digital systems. Access to academic services can be done anywhere and anytime with the help of mobile or student smartphone itself.

To see the impact of social media on changes in student social behavior, the same test was carried out using non-parametric statistical analysis which can be seen in the following table:

\begin{tabular}{lll|c|c}
\hline \multicolumn{4}{c}{ Correlations } \\
\hline \multirow{2}{*}{ Spearman's rho } & \multirow{2}{*}{ SocMed } & Correlation Coefficient & SocMed & Behaviour \\
\cline { 3 - 5 } & & Sig. (2-tailed) & 1.000 & $.681^{* *}$ \\
\cline { 3 - 5 } & $\mathrm{N}$ & 186 & .001 \\
\cline { 3 - 5 } & \multirow{2}{*}{ Behavior } & Correlation Coefficient & $.681^{* *}$ & 186 \\
\cline { 3 - 5 } & & Sig. (2-tailed) & .001 &. \\
\cline { 3 - 5 } & $\mathrm{N}$ & 186 & 186 \\
\hline
\end{tabular}

The impact of social media on changes in student social behaviour can be seen from the relationship between Social Media variables with changes in social behaviour in students based 
on table 3.3. $=0.001$ smaller than the value $\alpha=0.05$, then it can be said Ho $=$ rejected. Thus, social media has a significant influence on changes in student learning behaviour at universities in Garut Regency, which is $68.1 \%$ or very strong. The strong influence of social media on changes in social behaviour does indeed prove that social media is now the most widely used communication media by people in the world, especially the younger generation. Social media is now the mass media of the digital area (Bowles, et al., 2018).

Future research on the specific opportunities that social media provides for the millennial generation to feel inspired by Janicke-Bowles, Narayan, and Seng would be important, considering the detrimental effects that research has observed from social media use in general (McDool et al., 2016; Hanna et al., 2017, Bowles, et al., 2018: 132-133). Social media is participatory, socially engaging, and reciprocal. It thus provides opportunities not only for information sharing but also for social networking and interactive engagement (Benetoli et al., 2015). Social media is one of the factors that can influence the social behaviour of people today. According to Suparno and Sandra (2011), cyberspace like social media is a great revolution capable of changing human behaviour today. Social media is also a cultural transformation, especially in social interactions (Thurlow, 2004). That the presence of technology forms a culture called technopoly where technology is deified and handed over to control all aspects of life (Postman, in Straubhaar, 2010).

\section{Conclusion}

Social media is an online media that users can easily participate, share and create anything. Through the use of social media that is developing at this time, education is possible to apply a learning process that is not only limited by classrooms that are insulated from walls but also can be done by the use of various types of social media. Formal use of social media can be interpreted as a combination of learning in analogue and online. The ease of accessing various information related to science that is needed by students is what later caused the students in Garut district to be particularly enthusiastic in using the facilities available through social media.

The use of social media in the learning process is considered effective to support the expected outcomes of students in the Garut district. Changes in learning behaviour that arise as a result of the use of social media can be seen from the increasing level of use of social media in the learning process, both during class lectures and when exploring information about science related to various subjects outside the classroom.

In addition to changes in learning behaviour, the use of social media also has an impact on the changes in the social behaviour of students in Garut district. This is indicated by the depletion of the level of social interaction between students in the surrounding environment. The use of social media more often makes them seem apathetic towards the surrounding community. For those who use social media, interaction with colleagues or family is considered more fun if done through social media rather than meeting and talking directly.

\section{Referensi}

[1] Amofah-Serwaa, N., \& Dadzie, P. S. (2015). Social Media use and its implication on child behaviour: A Study of a basic school in Ghana. International Journal of Social Media and Interactive Learning Environment, 3(1), 49-62. 
[2] APJII, 2012, Profil Pengguna Internet Indonesia, Asosiasi Pengguna Jasa Internet Indonesia.

[3] Bowles, Narayan1, and Anja Seng. (2018). Social Media for Good? A Survey on Millennials' Inspirational Social Media Use. The Journal of Social Media in Society Fall 2018, Vol. 7, No. 2, Page 120-140

[4] Boyd, D. M., \& Ellison, N. B. (2007). Social Network Sites: Definition, History, and Scholarship. Journal of Computer-Mediarted Communication, 2007: article 11.

[5] Buente, W., \& Robbin, A. (2008). Trends in Information Behavior: 2000-2004. Journal of the American Society for Information Science. 2008 June 2, 22-34.

[6] Hanna, E., Ward, L.M., Seabrook, R.C., Jerald, M., Reed, L., Giaccardi, S., \& Lippman, J.R. (2017). Contributions of social comparison and self-objectification in mediating associations between Facebook use and emergent adults' psychological well- being. Cyberpsychology, Behavior and Social Networking, 20(3), 172-179. doi:10.1089/cyber.2016.0247.

[7] Kaplan, A. M. \& Haenlein, M. (2010). Users of the World, Unite! The Challenges and Opportunities of Social Media. Business Horizons.

[8] Kross, E., Verduyn, P., Demiralp, E., Park, J., Lee, D.S., Lin, N. ...\& Ybarra, O. (2013). Facebook use predicts declines in subjective well-being in young adults. PLoS ONE, 8(8), e69841. https://doi.org/10.1371/journal.pone.0069841

[9] Lin, L.Y., Sidani, J.E., Shensa, A., Radovic, A., Miller, E., Hoffman, B.L., ... \& Primack, B.A. (2016). Association between social media use and depression among U.S. young adults. Depression and Anxiety, 33(4), 323-331. doi:10.1002/da.22466

[10]Lup, K., Trub, L., \& Rosenthal, L. (2015). Instagram \#instasad?: Exploring associations among Instagram use, depressive symptoms, negative social comparison, and strangers followed. Cyberpsychology, Behavior and Social Networking, 18(5), 247-252. doi:10.1089/cyber.2014.0560

[11] McDool, E., Powell, P., Roberts, J., \& Taylor, K. (2016). Social media use and children's wellbeing. $\quad$ IZA Discussion $\quad$ Paper $\quad$ No. 10412; https://papers.ssrn.com/sol3/papers.cfm?abstract_id=2886783 (accessed May 4. 2017)

[12] McQuail, Denis, (2011). Teori Komunikasi Massa Buku. 6th edition. Jakarta:Salemba Humanika.

[13] Nasrullah, R. (2017). Media Sosial (Prespektif Komunikasi, Budaya, dan Sosioteknologi). Bandung: Simbiosa Rekatama Media.

[14] Neuman, W. L. (2013). Social Research Methods: Qualitative and Quantitative Approaches ter. Edina T. Sofia. Jakarta: PT Indeks.

[15] Pittman, M., \& Reich, B. (2016). Social media and loneliness: Why an Instagram picture may be worth more than a thousand Twitter words. Computers In Human Behavior, 62, 155-167. doi:10.1016/j.chb.2016.03.084

[16] Schwartz, H. A., Eichstaedt, J. C., Kern, M. L., Dziurzynski, L., Ramones, S. M., Agrawal, M., et al. (2013). Personality, Gender, and age in the language of social media: The openvocabulary approach. Journal of Personality and Social Psychology, 3, 2013, September $25,10-20$.

[17] Soliha, S.,F. (2015). Tingkat ketergantungan pengguna media sosial dan Kecemasan sosial. JURNAL INTERAKSI, Vol. 4 No. 1, Januari $2015: 1$ - 10

[18] Straubhaar, J., LaRose, R., and Davenpo, L, 2010, Media Now: Understanding Media, Culture, and Technology, 7th edition, Wadsworth, Cengage Learning, United States of America. 
[19] Sudjana, N. (2014). Penilaian Hasil Proses Belajar Mengajar. Bandung: PT Remaja Rosdakarya.

[20] Supratman, L. P., \& Wahyudin, A. (2017). Digital media literacy to higher students in Indonesia. International Journal of English Literature and Social Sciences, 2(5), 51-58.

[21] Thurlow, C., Lengel, L., and Tomic, A, 2004, Computer Mediated Communication Social Interaction And The Internet, Sage Publications, London, Thousand Oaks, and New Delhi.

[22] Tromholt, M. (2016). The Facebook experiment: Quitting Facebook leads to higher levels of well-being. Cyberpsychology, Behavior, And Social Networking, 19(11), 661-666. doi:10.1089/cyber.2016.0259

[23] Woods, H.C., \& Scott H. (2016). \#Sleepyteens: Social media use in adolescence is associated with poor sleep quality, anxiety, depression and low self-esteem. Journal of Adolescence, 51, 41-49. doi:10.1016/j.adolescence.2016.05.008

[24] Yang, C. (2016). Instagram use, loneliness, and social comparison orientation: Interact and browse on social media, but don't compare. Cyberpsychology, Behavior, And Social Networking, 19(12), 703-708. doi:10.1089/cyber.2016.0201

[25] Yoo, Joseph. Et.al. Social Networking Site as a Political Filtering Platform: Predicting the Act of Political Unfriending and Hiding. The Journal of Social Media in Society Fall 2018, Vol. 7, No. 2, Page 92-119.

[26] Adewuyi, E.O., Adefemi, K. (2016). Behavior Change Communication Using Social Media: A Review. International Journal Communication and Health. Curtin University.

[27] Shaffer-Hudkins, E., Johnson, N., Melton, S., \& Wingert, A. (2014). Social media use among individuals with diabetes. International Journal of communication and health, 4: 38 -43 . 